\title{
Present and Future Trends in Translation Studies
}

\author{
Haru Deliana Dewi \\ Faculty of Humanities, Universitas Indonesia \\ harudd.dewi7@gmail.com
}

\begin{abstract}
Translation Studies is a relatively new discipline in the world, and in Indonesia it is not much heard of, let alone studied by. Moreover, none of the universities in this country has Translation Studies as one of its study programs or departments. Translation is still considered part of a linguistics department or literature department. Thus, this paper will explain this 'new' discipline, what it covers, and the trends it has in the present and future times. It is expected that this paper will be an eye-opener for many academicians in Indonesia to be aware of Translation Studies as an independent discipline which draws from many disciplines and to encourage people to learn more about this discipline.
\end{abstract}

Keywords: Translation Studies, present and future trends, independent discipline

\section{INTRODUCTION}

Translation Studies (TS) has been flourishing since 1970s in the world. However, this discipline has grown further only in many developed countries, such as the USA, the UK, Australia, and European countries. In Asia, TS has developed in China and several Arab countries. What about in Indonesia? Based on a little research I did for my presentation at Polinema Malang in November 2016, I discovered that TS has not really developed in this country. Translation is still considered part of a linguistics or literature department.

This paper will not attempt to explore why TS has not developed well in Indonesia and why translation is still part of a linguistics or literature department in the universities in this country. Instead, it will explain what TS is, what it covers, and present and future trends in TS. First of all, TS, according to Snell-Hornby (1995), is an independent discipline, and this idea has appeared since the work of Nida in 1960s and Bassnett-Mcguire (1980). Holmes (1972) has even been considered as the founding father of TS, as he pioneered the TS map (Holmes' Map) which shows what the discipline of TS should consist of. The following is the Holmes' Map:

Figure 1. Holmes' map (based on Holmes 1988)

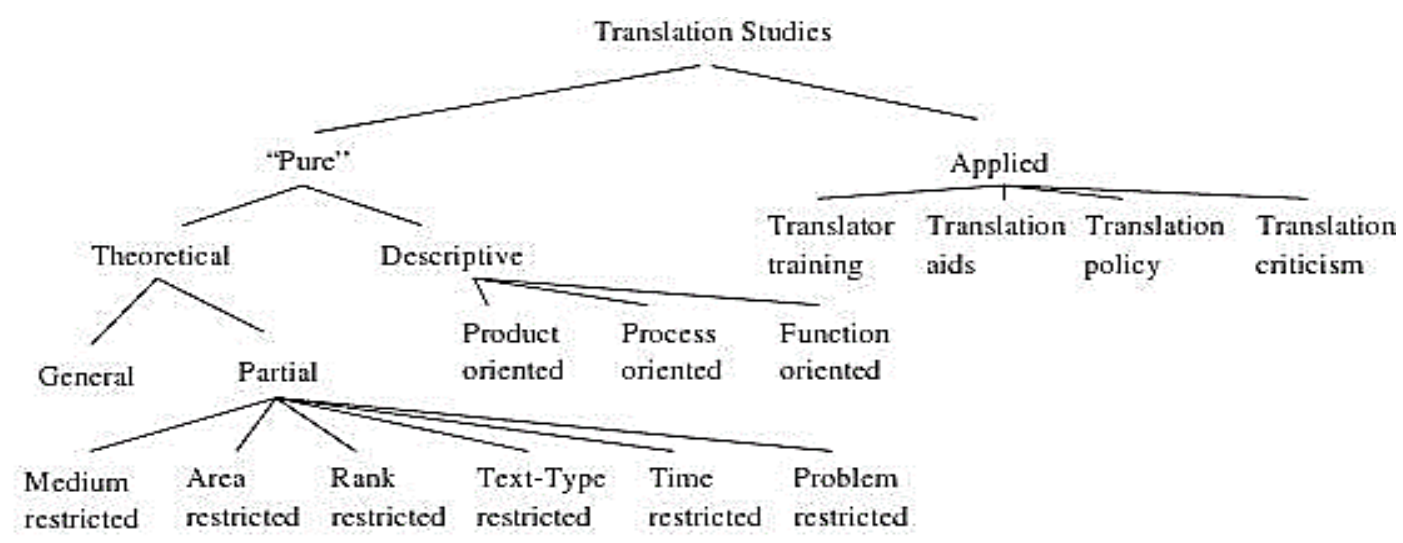


From the figure above, we can see how TS has a variety of fields under it, which draws from many disciplines. For example, under the Applied TS, translation aids which include CAT (Computer-Assisted Translation) Tools, MT (Machine Translation), TM (Translation Memory), Terminology Management, and others can involve the discipline of computer science since those tools require the skills to design their application. Furthermore, the process-oriented DTS (Descriptive Translation Studies) is about the 'black box' of a translator or an interpreter, which refers to the study of cognition. The time-restricted partial theoretical TS refers to the study of history of either translation or interpreting. Function-oriented DTS could involve sociology, as it discusses the function of a translation in a society. Those examples indicate how TS is also a multidisciplinary study. Inasmuch as TS draws from many disciplines, the following will explore further the present and future trends in this field.

\section{PRESENT AND FUTURE TRENDS IN TS}

Although TS is no longer part of linguistics, linguistics is part of TS still. A similar thing goes to literature. One of the current trends in TS is the use of Critical Discourse Analysis (CDA) in TS research. Just like Discourse Analysis (DA), text analysis is an essential part too in CDA, but CDA "aims at revealing structures of power and unmasking ideologies" (Wodak and Meyer, 2009:8) and investigates social issues as well as having the objective to affect social practice (Saldanna and O'Brien, 2013:55). Moreover, texts based on the perspective of CDA are not considered as linguistic units but as semiotic units. In TS, the use of CDA has been introduced by the work of Hatim and Mason $(1990,1997)$, and since then it has been widely applied to research issues of ideology in translations of written texts. Some examples of applying the use of CDA in TS research are to discover a different ideology between one magazine company and another in the translation of the same topic article, how a translation result of the same speech done by two political parties will be dissimilar, and so on. Several recent works of TS using CDA are "Critical Discourse Analysis and Translation Studies: Translations, Recontextualization, Ideology" by Isabela Ieţcu-Fairclough (2008), and "Applying Critical Discourse Analysis in Translation of Political Speeches and Interviews” by Mehdi Mahdiyan, Muhammad Rahbar, and Seyed Mohammad Hosseini-Maasoum (2013).

The use of corpus linguistics (CL) or corpora has become one of the trends too in TS. According to Bowker and Pearson, a corpus is "a large collection of authentic texts that have been gathered in electronic form according to a specific set of criteria" (2002:9). In TS, the use of corpora at first was to describe the differences between translation texts and non-translation texts. Nowadays, corpora or CL has been applied in research to focus more on social problems than on linguistic structure per se (Mautner, 2009:33). Thus, the studies using CL can analyze the ideology applied in a translation, the style used by certain translators, the differences of translation results between human translators and machine translation, etc. Several recent works using CL or corpora in TS are "Principles of Corpus Linguistics and their Application to Translation Studies Research" by Gabriela Saldanha (2009) and "Discovering Translation Methods in a Bilingual Newspaper Using Corpus Tools” by Haru Deliana Dewi (2016).

Another trend in TS is the application of cognitive studies in TS research. Cognitive studies are usually involved in translation process research because it attempts to comprehend 
the behaviour, competence, and expertise of translators and interpreters, the cognitive processes, and the connection between cognition and the translated or interpreted products (Saldanha \& O Brien, 2013:109). Metacognition, working memory (WM), cognitive rhythm, and pauses are also common topics in this type of research. The methodology of translation process research commonly applies software or tools, such as think-aloud protocols (TAPs), keystroke logging software, screen recording software, eye tracking device. For instance, Hans-Peter Krings was the first TS scholar to observe at the translator's mind using the method of TAPs. He discovered that professional translators activate their knowledge and experience and focus on the text, while novice translators or learners concentrate more on words and formal elements. Some recent works using cognitive studies in TS research are "On Paradigms and Cognitive Translatology" by Ricardo Muñoz Martín (2010) and Cognitive Explorations of Translation by Sharon O'Brien (2011).

Localization is also another trend in TS deriving from translation industry, and it has incorporated the elements of the equivalence paradigm. Since 1980s, US software publishers have undertaken "translation" of products for European and Asian markets. As a result of this, 'localization' was born and emerged as an industry in 1990s. Localization is the preparation of a product for a new locale, and a locale is a set of linguistic, economic, and cultural parameters for the end-use of the product (Pym, 2010). Localization is one of the fastest-growing sectors of the international economy, and localization vendors provide critical international business services, such as webpage translation and software localization for multilingual versions of software. A couple of recent works on localization are "Translation 2.0 The localization of institutional websites under the scope of functionalist approaches" by Alberto Fernandez Costales (2009) and "A Paradigm Shift in Academic Translation Teaching and Its Reflection on the Localization Industry in the Digital Age” by Mehmet Cem Odacioğlu and Șaban Köktürk (2015).

Finally, cultural translation, which heads to the opposite direction of localization, is also one of the trends in TS. Cultural translation is a process in which there is no source text and usually no fixed target text and the focus is cultural processes rather than products. The main cause of cultural translation is the movement of people (subjects) rather than the movement of texts (objects). It also refers to the cultural effects of translation and draws on several broad concepts of translation developed in (1) social anthropology, where the task of an ethnographer is to describe the foreign culture; (2) actor-network theory ("translation sociology"), where the interactions that form networks are considered as translations; and (3) sociologies that study communication between groups in complex, fragmented societies, particularly those shaped by migration (Pym, 2010). This cultural translation is very much influenced by the development of cultural studies and address problems in postmodern sociology, postcolonialism, migration, cultural hybridity, and much more. Several TS scholars whose works involve cultural translation are Michael Cronin (1996) in Translating Ireland, Maria Tymoczko (1999) in Translation in a Postcolonial Context, and Homi K. Bhabha in a chapter called "How Newness Enters the World:

Postmodern Space, Postcolonial Time, and the Trials of Cultural Translation" in The Location of Culture (1994/2004). 


\section{CONCLUSION}

To summarize, there are several present trends in TS which might continue to the future. Those trends are the use of CDA and corpora or CL, and the involvement of cognitive studies in TS research. Another trend is the development of localization in translation industry. The last trend mentioned in this paper is the research on cultural translation which has grown along the establishment of cultural studies. All these trends indicate the involvement of other disciplines in Translation Studies research, which confirms the fact that TS is a multidisciplinary and independent study.

\section{REFERENCES}

Bhabha, Homi K. (1994/2004). The Location of Culture. London \& New York: Routledge. Bassnett.

Mcguire, Susan. (1980/1993). Translation Studies. London \& New York: Routledge. Bowker, Lynne and Pearson, Jennifer. (2002). Working with Specialized Language: A Practical Guide to Using Corpora. London \& New York: Routledge.

Cronin, Michael. (1996). Translating Ireland: Translation, Languages, Cultures. Cork University Press.

Costales, Alberto F. (2009). "Translation 2.0 The localization of institutional websites under the scope of functionalist approaches" in Dries De Crom (ed.) Translation and the (Trans)formation of Identities. Selected Papers of the CETRA Research Seminar in Translation Studies 2008, pp.118. Accessed from http://www.kuleuven.be/cetra/papers/papers.html, on 10 Oct 2017.

Dewi, Haru D. 2016. "Discovering Translation Methods in a Bilingual Newspaper Using Corpus Tools." In the Proceedings of the 2016 Atmajaya University Translation Conference (TransCon 6), presented on 8 October 2016, pp. 36-45.

Hatim, Basil and Mason, Ian. (1990, 1997). Discourse and the translator. Longman Publisher.

Holmes, James S. (1972). "The Name and Nature of Translation Studies." Presented in the Translation Section of the Third International Congress of Applied Linguistics in Copenhagen, 21-26 August 1972.

Ieţcu-Fairclough, Isabela. (2008). "Critical Discourse Analysis and Translation Studies: Translations, Recontextualization, Ideology” in Diacronia, pp.67-72, accessed from http://www.diacronia.ro/ro/indexing/details/A9793/pdf on 10 Oct 2017.

Krings, Hans-Peter. (1986). Was in den Köpfen von Ü̈bersertzern vorgeht. Tübingen: Gunter Narr Verlag.

Mahdiyan, Mehdi, Rahbar, Muhammad, and Hosseini-Maasoum, Seyed Mohammad. (2013). "Applying Critical Discourse Analysis in Translation of Political Speeches and Interviews" in Academic Journal of Interdisciplinary Studies, Vol.2 No.1, March 2013, pp.3547.

Mautner, Gerlinde. (2009). "Corpora and Critical Discourse Analysis," in Paul Baker (ed.) Contemporary Corpus Linguistics. London \& New York: Continuum, pp. 32-46.

Muñoz Martín, Ricardo. (2010). “On Paradigms and Cognitive Translatology,” in Gregory Shreve and Erik Angelone (eds.) Translation and Cognition. Amsterdam \& Philadelphia: John Benjamins, pp. 169-186.

Nida, Eugene and Taber, Charles. (1969). Theory and Practice of Translation. London United Bible Societies.

O’Brien, Sharon. (2011). Cognitive Explorations of Translation. London: Continuum. 
Odacioğlu, Mehmet Cem and Köktürk, Șaban. (2015). "A Paradigm Shift in Academic Translation Teaching and Its Reflection on the Localization Industry in the Digital Age" in Journal of Language Teaching and Research, Vol. 6, No. 6, pp. 1175-1180, November 2015.

Pym, Anthony. (2010). Exploring Translation Theories. London \& New York: Routledge.

Saldanha, Gabriela. (2009). "Principles of Corpus Linguistics and their Application to Translation Studies Research" in Tradumática 7. Available at http://webs2002.uab.es/tradumatica/revista/num7/articles/01/art.htm, accessed on 10 Oct 2017.

Saldanha, Gabriela and O Brien, Sharon. (2013). Research Methodologies in Translation Studies. London \& New York: St. Jerome Publishing.

Snell-Hornby, Mary. (1995). Translation Studies: an Integrated Approach. Amsterdam \& Philadelphia: John Benjamins Publishing Company.

Tymoczko, Maria. (1999). Translation in a Postcolonial Context: Early Irish Literature in English Translation. Manchester: St. Jerome Publishing.

Wodak, Ruth and Meyer, Michael. (2009). "Critical Discourse Analysis: History, Agenda, Theory, and Methodology”, in Ruth Wodak and Michael Meyer (eds.) Methods of Critical Discourse Analysis. California \& London: Sage, pp. 1-13. 